\title{
Nutrition and osteoporosis prevention and treatment
}

\author{
Jalal Hejazi ${ }^{1}$, Ali Davoodi ${ }^{2}$, Mohammadreza Khosravi $^{2}$, Meghdad Sedaghat $^{3}$, Vahideh Abedi ${ }^{4}$, \\ Sima Hosseinverdi ${ }^{5}$, Elham Ehrampoush ${ }^{6}$, Reza Homayounfar ${ }^{6, *}$, Layla Shojaie ${ }^{7}$
}

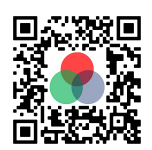

Use your smartphone to scan this QR code and download this article

${ }^{1}$ Department of biochemistry and nutrition, Faculty of medicine, Zanjan university of medical scinces, Zanjan, Iran

${ }^{2}$ Student research committee, Fasa university of medical sciences, Fasa, Iran

${ }^{3}$ Assistant professor of internal medicine, Department of internal medicine, Imam hossein Hospital, Shahid Beheshti University of medical science, Tehran, Iran

${ }^{4} \mathrm{MSc}$ Student of physical activity and health promotion, Department of Biomedicine and Prevention, Faculty of Medicine and Surgery, Tor Vergata University of Rome, Rome, Italy

${ }^{5}$ Department of physical medicine and rehabilitation, neuromusculoskeletal research center, Iran university of medical sciences, Tehran, Iran

${ }^{6}$ Noncommunicable diseases research center, Fasa University of Medical Sciences, Fasa, Iran

${ }^{7}$ Research Center of Liver Diseases, Keck School of Medicine, Department of Medicine, University of Southern California, Los Angeles, CA, USA

\section{Correspondence}

Reza Homayounfar, Noncommunicable diseases research center, Fasa University of Medical Sciences, Fasa, Iran

Email: r_homayounfar@yahoo.com History

- Received: Dec 11, 2019

- Accepted: Mar 25, 2020

- Published: Apr 26, 2020

DOI : 10.15419/bmrat.v7i4.598

\section{Check for updates}

\section{Copyright}

() Biomedpress. This is an openaccess article distributed under the terms of the Creative Commons Attribution 4.0 International license.

\begin{abstract}
Introduction: Osteoporosis falls among the major general health issues, specifically in the elderly, and is a widespread disease these days. According to various studies, good nutrition plays a significant role in osteoporosis prevention and treatment. The aim of this study was to conduct an extensive literature review on the effects of different nutrients to understand how macronutrients, micronutrients, and non-nutritive substances affect bone health. Methodology: To find relevant studies, the main keyword "osteoporosis" was searched in combination with "zinc," "vitamin K," " "phosphorus," " vitamin D," " calcium," "'lipid," " protein," and " phytoestrogens" in PubMed (MEDLINE), Web of Science, SID, and Iran Medex databases. Findings: The most important element for bone health is calcium, which has a direct link to the bone mass density (BMD). In the case of calcium deficiency, high phosphorus content can damage bone tissue. The acceptable ratio of phosphorus to calcium is 0.5-1.5:1. Vitamin D is another important nutrient for bones; serum levels of vitamin D less than $20 \mathrm{ng} / \mathrm{ml}$ reduce bone density and increase the risk of fracture. High protein intake results in calcium excretion and loss of bone mass. In addition, calcium deficiency increases the risk of osteoporosis, specifically in the elderly. According to the literature, there is an inverse correlation between saturated fats and BMD. Vitamin K and magnesium deficiencies are correlated with $\mathrm{BMD}$ reduction and increased risk of osteoporosis. Copper and zinc are used as co-factors in the formation of collagen and elastin, and in mineralization of bone. As a result, deficiency of these elements may disrupt the process of incorporating minerals into the bone matrix. Conclusion: Good nutrition may play a significant role in osteoporosis prevention and treatment. Indeed, a healthy diet containing calcium (1,200 mg/day); vitamin D (600 IU); and certain amounts of protein, magnesium, and vitamin K can contribute greatly to bone health.
\end{abstract}

Key words: Osteoporosis, Nutrition, Calcium, Vitamin D

\section{INTRODUCTION}

Osteoporosis is among the major health issues, specifically in the elderly. It is one of the main causes of morbidity and mortality in this group of people $\mathrm{e}^{1,2}$. In addition, it imposes a profound financial burden on the healthcare system every year ${ }^{3}$. Today, because of the rapid growth of the elderly population, osteoporosis has become an epidemic in some societies ${ }^{4}$. According to the definition of the World Health Organization, osteoporosis is a systematic skeletal disease, characterized by the loss of bone mass density (BMD) and damage to the microstructure of bone tissue, leading to increased bone vulnerability and risk of fracture ${ }^{5,6}$. Although osteoporosis can affect all bones, the wrist bones, lumbar vertebrae, and pelvis are more vulnerable to it ${ }^{7}$. There are different and, sometimes, contradictory reports about the prevalence and incidence of osteoporosis in different societies. These reports contain differences in definitions, BMD measurement techniques, location of density measurement, and research population. On average, the prevalence rates of osteoporosis in men and women over 50 years old have been reported as $1: 3$ and 1:8, respectively, indicating a higher risk of osteoporosis in women ${ }^{8}$. Typically, the annual bone turnover is $0.2-0.5 \%$ between ages 40 and 45 years ${ }^{1}$. Osteoporosis is a multi-factor disease in which genetics, age, gender, race, weight, and consumption of certain medications (e.g., corticosteroids and thyroid hormones), as well as some diseases (rheumatoid arthritis and gastrointestinal disorders), can affect the BMD and consequently bone health.

Lifestyle is among the most important factors that impact bone density. Factors such as physical activity, exercise, nutrition habits, and alcohol/tobacco consumption are correctable and, thus, have been taken into consideration as important. According to different studies, good nutrition plays a significant role in osteoporosis prevention. In this regard, the most important nutrients are calcium and vitamin D. In addition, paying attention to nutrition is an important component in the treatment and rehabilitation 
of osteoporosis patients. In contrast, poor nutrition can slow down the recovery process and increase the risk of bone fracture. Devoting extra attention to micronutrients, such as calcium and vitamin $\mathrm{D}$, has led to awareness of other micronutrients with an important role in bone health ${ }^{9}$.

The goal of this study was to conduct an extensive literature review on the effects of different nutrients, specifically macronutrients (e.g., protein and fat) and micronutrients (e.g., calcium, vitamin D, phosphorus, vitamin $\mathrm{K}$, magnesium, and zinc), and a non-nutritive substance (phytoestrogens) on bone health. The aim of the analysis was to provide good diet solutions for osteoporosis prevention and treatment.

\section{METHOD}

Searches were carried out using the PubMed (MEDLINE), Web of Science, SID, and Iran Medex databases, with the main keyword "osteoporosis," in combination with "zinc," "vitamin K," "phosphorus," "vitamin D," "calcium," "lipid," "protein," and "phytoestrogens," among articles published between 2000 and 2017. The reference list of articles deemed relevant to the review was also further evaluated. This database searching identified 625 articles, all of which were in English. After the screening step, 70 relevant clinical articles were assessed for eligibility. Of these, 30 poor articles were excluded, and the remaining ones were reviewed and prioritized according to the validity of methods, clarity of results, and recency of data.

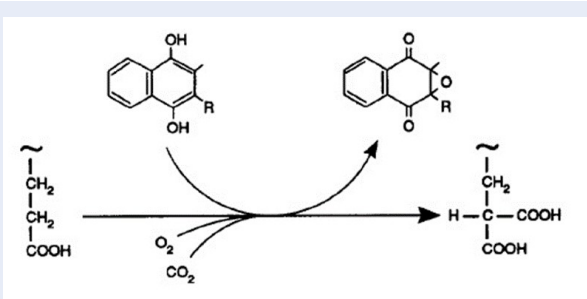

Figure 1: Vitamin K dependent carboxylation.

\section{MACRONUTRIENTS AND OSTEOPOROSIS}

\section{Protein}

Despite several studies on the effects of the type and amount of protein intake on bone metabolism, findings are still contradictory. According to studies, high protein intake can result in increased urinary excretion of calcium, negative calcium balance, and loss of bone mass in both young and old people ${ }^{10}$. This is mainly due to the acidic environment created by protein metabolism, specifically animal proteins, in the human body. This acidic environment is created because of sulfur-containing amino acids and the production of acidic equivalents ${ }^{11}$. In fact, it is argued that the bones release ions, such as calcium carbonate, to neutralize this acidic environment, leading to increased urinary excretion of calcium and to BMD $\operatorname{loss}^{12}$. In addition, other studies have shown that although animal proteins have sulfur-containing amino acids, they are more effective than vegetable proteins in reducing the risk of pelvic fractures ${ }^{13}$. However, other studies have suggested that low protein intake is a risk factor for osteoporosis, and is correlated with low $\mathrm{BMD}^{14}$. Low protein intake also increases the risk of fracture in the elderly ${ }^{15}$.

Conversely, increased protein intake by different mechanisms can positively affect bone health through the absorption of calcium, through increased secretion of insulin-like growth factor 1 (IGF-1), and promotion of lean body mass ${ }^{16,17}$. Some studies have shown that increased protein intake improves calcium absorption ${ }^{18,19}$; however, other studies have rejected this correlation. Increased protein levels can also affect liver products and growth factor function ${ }^{20}$. Because IGF-1 can increase the density and strength of bones ${ }^{21}$, proteins can contribute to bone mass maintenance through the production of IGF- ${ }^{22}$. Some cross-sectional studies have shown a positive relationship between protein intake and BMD, whereas other studies have not reported such correlations ${ }^{23}$. Observational studies by Michaelsson et al. ${ }^{24}$ and Lacey et al. ${ }^{25}$ have shown that among the hospitalized elderly, women receiving $1 \mathrm{~g} / \mathrm{kg}$ of protein had greater BMD in their lumbar vertebrae, femoral neck, and thighbone than women receiving a smaller amount of protein. As a result, Rapuri et al. have recommended the intake of $1 \mathrm{~g} / \mathrm{kg}$ of protein, which is slightly higher than the standard recommendation $(0.8 \mathrm{~g} / \mathrm{kg})$ for maintenance of bone health ${ }^{26}$. In a study by Meyer et al., the authors did not find any significant correlation between protein intake and the risk of pelvic fracture. However, increased protein intake in people with calcium deficiency was shown to increase the risk of pelvic fracture ${ }^{27}$. According to a meta-analysis conducted to investigate the relationship of protein intake and bone health, a weak correlation was observed between protein intake and bone mass in lumbar vertebrae; however, this relationship was not observed in the pelvic bone. Therefore, increased protein intake has little impact on bone health; however, this effect does not necessarily reduce the risk of bone fracture in the long term ${ }^{12}$. 


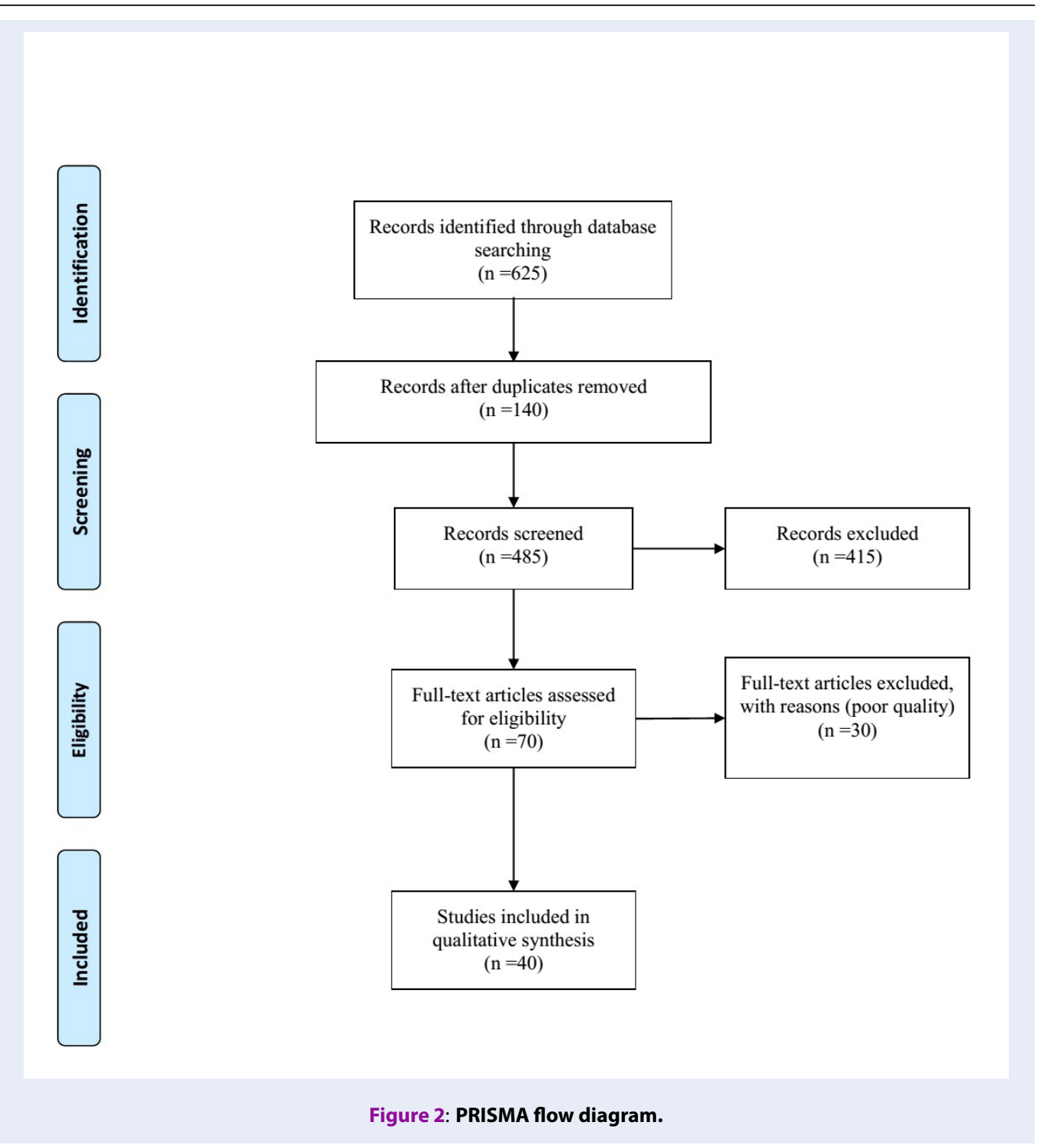

Fat

There are several lines of evidence showing that the type and amount of dietary fat can significantly affect bone health. It has been observed that there is an inverse relationship between the intake of saturated fatty acids (SFA) and BMD. The proposed mechanisms for this phenomenon include:

1. SFA decreases the membrane fluidity of intestinal epithelia cells, thereby reducing the uptake of calcium by small intestinal brush border cells.

2. An SFA-enriched diet inhibits bone mineralization.

3. It has been shown that SFA suppresses the differentiation of rat bone marrow mesenchymal stem cells.
4. According to some reports, oxidized lipids increase osteoclast cell differentiation (bone resorbing cells). Therefore, people who eat an SFA-enriched diet (mostly from animal fats) are more at risk for osteoporosis

Among non-saturated fatty acids, the ratio of omega3 to omega- 6 plays an important role in the regulation of osteoblast and osteoclast activities. According to studies, prostaglandin E2, leukotriene B4, interleukin-1, and tumor necrosis factor are all capable of increasing bone mineral incorporation $^{28}$. Omega- 6 fatty acids are known to increase the production of eicosanoids and cytokines, whereas omega- 3 fatty acids inhibit their production ${ }^{29}$. In addition, omega- 3 fatty acids increase the absorption 
of calcium and decrease its urinary and fecal excretion $^{30}$. Despite significant progress in the treatment of cardiovascular diseases and osteoporosis, these diseases are still the major causes of mortality among the aging population ${ }^{31}$. Recent evidence suggests that they share a common etiological factor in that hyperlipidemia not only is correlated with atherosclerotic plaque but also results in osteoporosis, following a similar biological mechanism that includes lipid oxidation $^{32}$. Animal studies have revealed that a highfat diet has a destructive impact on bone health because some fatty acids induce bone destruction. The following mechanisms mediate those effects: calcium absorption changes, prostaglandin synthesis, formation of osteoblasts, and lipid oxidation. Despite reliable results from broad animal studies in vitro, there are scant studies in humans in this regard. Results from studies on women were consistent with those from animal studies, indicating that the amount of fat intake is positively associated with risk of fracture but inversely correlated with bone density ${ }^{27}$.

\section{MICRONUTRIENTS AND OSTEOPOROSIS}

\section{Calcium}

Undoubtedly, calcium is the most important nutrient for bone health. This is because $99 \%$ of the calcium requirement of the body is stored in the bones. In general, $67 \%$ of the bones is made of mineral, specifically in the form of hydroxyapatite. The remaining $33 \%$ is made of organic substances, specifically collagen. The recommended amount of calcium depends on age $(1,000 \mathrm{mg} /$ day for men and women, and 1,200 $\mathrm{mg} /$ day for people over 50 years) ${ }^{27}$. When calcium intake is insufficient, serum calcium levels start decreasing, causing a series of consequences. First, increased secretion of parathyroid hormone (PTH) results in the resorption of bones and release of their content to the blood, which inhibits the reduction of the serum calcium level. Continuation of this phenomenon decreases BMD and increases the risk of osteoporosis $^{33}$. Among the total of 139 articles published since 1975 on the relationship of calcium intake and bone health, 52 articles have been interventional studies with controls, of which 50 articles have reported that calcium intake increases BMD during the growing age, decreases BMD loss in the elderly, and reduces the risk of bone fracture. Three-fourths of the 86 observational studies also indicate a positive correlation between calcium intake and bone health. In general, this evidence reveals the important role of calcium in bone health ${ }^{34}$. In response to calcium deficiency, the body reduces bone mass with the help of a bone degradation mechanism to maintain the ionized calcium level of extracellular fluid.

Calcium deficiency is associated with many other consequences. Dietary calcium deficiency is a major cause of childhood rickets in developing countries ${ }^{35}$. Calcium plays a significant role in osteoporosis prevention because the calcium level is directly related to BMD and bone health. Nevertheless, calcium is not adequate for bone health because vitamin $\mathrm{D}$ deficiency is an important factor in increasing calcium uptake by the intestines. This phenomenon lowers the absorption of calcium and results in reduced bone mass and increased risk of osteoporosis ${ }^{36}$. In addition, lactose increases the uptake of calcium in the intestines. Glucose and fructose have similar effects on calcium uptake, and thus may have a role in increasing calcium level and decreasing the risk of osteoporosis $^{34}$. Although the majority of studies have addressed the effectiveness of calcium supplementation in postmenopausal women, there is a limited number of studies showing the effectiveness of calcium supplementation for young men and premenopausal women ${ }^{35}$. Before menopause, BMD remains relatively constant in women, but it starts decreasing immediately afterwards. Therefore, because the intake of calcium and vitamin D is highly effective at achieving peak BMD, dietary or pharmacological intake of these substances can prevent excessive BMD loss after menopause $^{37}$. The main dietary source of calcium is dairy; nevertheless, those who do not receive adequate dietary calcium, for example, because of lactose intolerance, can use commercial supplements, such as acetate, lactate, gluconate, citrate, and calcium carbonate, among which the latter has the highest absorbability.

\section{Vitamin D}

Almost $90 \%$ of the vitamin D requirement for the body is made in the skin from exposure to sunlight, and a small amount of vitamin D is supplied from foods ${ }^{38}$. Vitamin D synthesis in the skin decreases under the effect of ultraviolet radiation or by aging, which is due to decreased duration of exposure to sunlight and skin production performance ${ }^{15}$. It seems that vitamin D deficiency is a widespread problem among the elderly in all countries except the US, where foods are fortified with vitamin $\mathrm{D}^{39}$. Although there is no consensus about the vitamin $\mathrm{D}$ requirement for the body, all scientists consider a serum level lower than $20 \mathrm{ng} / \mathrm{mL}$ as an ideal level to define vitamin $\mathrm{D}$ deficiency ${ }^{40}$. However, some scientists define this 
Table 1: Characteristics and details of thestudies used in this review

\begin{tabular}{|c|c|c|}
\hline Micronutrient & Effect on BMD & Mechanism \\
\hline Calcium & Increase & $\begin{array}{l}\text { When calcium intake is not enough, serum calcium level starts decreasing, causing } \\
\text { a series of consequences. First increased secretion of parathyroid hormone (PTH) } \\
\text { results in the resorption of bones and release of their content in blood, which inhibit } \\
\text { the reduction of serum calcium level. }\end{array}$ \\
\hline Vitamin D & Increase & $\begin{array}{l}\text { Vitamin D deficiency results in the secondary hyperparathyroidism, increased } \\
\text { bone turnover, bone loss, reduced minerals. Newly formed bone matrix in adults } \\
\text { is not mineralized. This phenomenon results in the development of osteomala- } \\
\text { cia.With respect to the children, vitamin D deficiency causes rickets through dis- } \\
\text { ruption of cartilage calcification }\end{array}$ \\
\hline $\begin{array}{l}\text { Phosphorus } \\
\text { (high intake } \\
\text { or inadequate } \\
\text { intake) }\end{array}$ & Decrease & $\begin{array}{l}\text { Low intake of phosphorus or its negative balance can result in reduced performance } \\
\text { of osteoblasts, but increased osteoclast activities, and thus bone turnover. In gen- } \\
\text { eral, what is more important than the role of phosphorus intake in bone health is } \\
\text { the intake ratio of phosphorus to calcium, which should be } 0.5-1.5: 1 \text {. }\end{array}$ \\
\hline Vitamin K & $\begin{array}{l}\text { Protective } \\
\text { effect }\end{array}$ & $\begin{array}{l}\text { Evidence show that low serum non-carboxylated osteocalcin and phylloquinone } \\
\text { are directly correlated with low BMD and increased risk of bone fracture caused by } \\
\text { osteoporosis. }\end{array}$ \\
\hline Magnesium & Increase & $\begin{array}{l}\text { Magnesium deficiency can result in endothelial dysfunction that causes damage to } \\
\text { bone health. In addition, magnesium deficiency leads to greater release of inflam- } \\
\text { matory cytokines and then bone remodeling and osteopenia. since magnesium } \\
\text { has mitogenic impact on osteoblasts, its deficiency inhibits cellular growth and re- } \\
\text { sults in the formation of larger and perfect hydroxyapatite crystals. So, osteoporo- } \\
\text { sis, expands and trabecules microfractures are appeared. Magnesium deficiency } \\
\text { indirectly affects bone structure though the regulation of PTH level and serum } \\
\text { 1,25(OH)2D3 level, which finally results in hypocalcemia. }\end{array}$ \\
\hline Zinc & Increase & $\begin{array}{l}\text { Zinc also stimulates the formation of bone osteoblasts, and prevents bone resorp- } \\
\text { tion by osteoclasts. Zinc also has a structural role in the bone matrix. This element, } \\
\text { as a cofactor of alkaline phosphatase, stimulates bone mineralization. }\end{array}$ \\
\hline Copper & Increase & $\begin{array}{l}\text { The role of copper in bone metabolism can first be connected to copper-related } \\
\text { enzyme, called lyzyl oxidase that is essential for the formation of chemical bonds } \\
\text { derived from lysine in collagen and elastin. Copper has a key role in bone resorp- } \\
\text { tion, which is done through superoxide dismutase enzyme, in which copper acts } \\
\text { as a cofactor }\end{array}$ \\
\hline Macronutrient & $\begin{array}{l}\text { Effect } \\
\text { BMD }\end{array}$ & Mechanism \\
\hline protein & contraversial & $\begin{array}{l}\text { 1. Increased protein intake by different mechanisms can positively affect bone } \\
\text { health through the absorption of calcium, and increased secretion of insulin like } \\
\text { growth factor } 1 \text { (IGF-1) as well as lean body mass. } \\
\text { 2. High protein intake results in increased urinary excretion of calcium, negative } \\
\text { calcium balance, and loss of bone mass in both young and old people }{ }^{10} \text {. This is } \\
\text { mainly due to the acidic environment created by protein metabolism }\end{array}$ \\
\hline SFA & decrease & $\begin{array}{l}\text { 1. SFA decreases the membrane fluidity of intestinal epithelia cell, and thus reduces } \\
\text { the uptake of calcium by small intestinal brush-border cells } \\
\text { 2. An SFA enriched diet inhibits bone mineralization. } \\
\text { 3. Oxidized lipids increase osteoclast cell differentiation. }\end{array}$ \\
\hline Non-SFA & increase & $\begin{array}{l}\text { 1. Omega- } 6 \text { fatty acids increase the production of eicosanoids and cytokines that } \\
\text { are capable of increasing bone mineral feeding. } \\
\text { 2. Omega- } 3 \text { fatty acids increase the absorption of calcium and decrease its urinary } \\
\text { and fecal excretion }\end{array}$ \\
\hline $\begin{array}{l}\text { Non-nutritive } \\
\text { sustances }\end{array}$ & $\begin{array}{l}\text { Effect } \\
\text { BMD }\end{array}$ & Mechanism \\
\hline phytoestrogen & increase & $\begin{array}{l}\text { first, through the activation of estrogen receptors causing the increased activa- } \\
\text { tion of osteoblasts, and second, through increasing the production of insulin-like } \\
\text { growth factor } 1 \text { (IGF-1) }\end{array}$ \\
\hline
\end{tabular}


deficiency level as $30 \mathrm{ng} / \mathrm{mL}$ and consider any vitamin $\mathrm{D}$ level lower than that as an important risk factor ${ }^{41}$. The current recommendation for vitamin $\mathrm{D}$ intake is $10 \mu \mathrm{g} /$ day in people aged $50-70$ years and $15 \mu \mathrm{g}$ /day in older people. Nevertheless, studies have shown that a higher dose of this vitamin (800-1,000 IU/day) may have good effects on bone health ${ }^{42}$. Indeed, vitamin D plays an important role in calcium and phosphorus homeostasis; its deficiency results in secondary hyperparathyroidism, increased bone turnover, bone loss, reduced minerals, and pelvic and other fractures ${ }^{15}$. With respect to children, vitamin D deficiency causes rickets through disruption of cartilage calcification. The newly formed bone matrix in adults is not mineralized. This phenomenon results in the development of osteomalacia ${ }^{33}$.

Vitamin D is hydroxylated in the liver to form 25hydroxy-vitamin $\mathrm{D}^{43}$. This substance is then converted into hydroxylated $1,25(\mathrm{OH}) \mathrm{D}_{3}$. The hydroxylation in the liver is activated by $\mathrm{PTH}$ and inhibited by phosphate. In addition, $25(\mathrm{OH}) \mathrm{D}_{3}$ limits biological activities ${ }^{44}$, whereas the active form of vitamin D [i.e., $1,25(\mathrm{OH})_{2} \mathrm{D}_{3}$ ] increases plasma calcium and phosphorus levels by affecting the kidneys, intestines, and bones. Binding of $1,25(\mathrm{OH})_{2} \mathrm{D}_{3}$ to its receptors in the intestines results in the synthesis of proteins in the intestinal cells that are involved in the transportation of calcium from the intestinal tract to the blood. These vitamin D receptors exist in other organs, such as bones, muscles, the pancreas, and the hypophysis ${ }^{19}$. The presence of $1,25(\mathrm{OH})_{2} \mathrm{D}_{3}$ in bone stimulates osteoblasts, thereby increasing the production of osteocalcin and alkaline phosphatase, and decreasing the production of type 1 collagen. The presence of $1,25(\mathrm{OH})_{2} \mathrm{D}_{3}$ also improves bone resorption in vitro. The production of $1,25(\mathrm{OH})_{2} \mathrm{D}_{3}$ is controlled directly by serum calcium and phosphate levels, and indirectly by calcium though the reduction of serum levels of $\mathrm{PTH}^{20}$. Reduced synthesis of $1,25(\mathrm{OH})_{2} \mathrm{D}_{3}$ results in a slight reduction of the serum calcium level, which increases the serum PTH level ${ }^{45}$. Secondary hyperparathyroidism is known as the main mechanism that causes vitamin D deficiency, leading to pelvic fracture. Several studies have reported the increased serum level of PTH in the elderly, which has been related to vitamin D deficiency ${ }^{46}$. This negative relationship between $1,25(\mathrm{OH})_{2} \mathrm{D}_{3}$ and PTH has been observed in not only the elderly but also postmenopausal women aged $45-65$ years ${ }^{47}$.

\section{Phosphorus}

It seems that the intake of the recommended amount of phosphorus (700 mg/day) does not have any negative impact on bone homeostasis. However, a high intake of phosphorus, specifically when it is associated with a low intake of calcium, can be harmful. In contrast, an adequate intake of phosphorus is essential for bone formation during the growth ages because low serum phosphate levels limit the formation and mineralization of bone ${ }^{48}$. In addition, low serum phosphorus levels can be regarded as an indicator of malnutrition, which is a risk factor for osteoporosis and fracture. Low intake of phosphorus or its negative balance can result in reduced performance of osteoblasts, but increased osteoclast activity and, thus, higher bone turnover ${ }^{49}$. In general, what is more important than the role of phosphorus intake in bone health is the intake ratio of phosphorus to calcium, which should be $0.5-1.5: 1^{50}$. A study in the US and Canada showed satisfactory intake of calcium in children and adolescents; however, the intake of calcium in adults, specifically young women, was poor. Although the dietary ratio of calcium to phosphorous was satisfactory in these regions (1:16), low intake of dairy foods, along with excessive consumption of foods rich in phosphorus or with added phosphorus, can increase this ratio to over 1:2. This increase can subsequently heighten the risk of osteoporosis ${ }^{51}$. In fact, the ratio of calcium to phosphorus, rather than the calcium or phosphorus content alone, is a determining factor in bone health and a predictor of osteoporosis. Thus, adequate levels of dietary calcium and phosphorus are very important for the health of bones $^{52}$.

In a study of the relationship of age and serum phosphorus levels in women, a significant correlation was observed between the phosphorus serum level, age, and osteoporosis. In fact, fat and phosphorus levels increased in postmenopausal women ${ }^{53}$.

\section{Vitamin K}

The vitamin $\mathrm{K}$ requirement of the body is supplied from two sources, but mainly from phylloquinone (K2), which exists in plant foods. The remaining vitamin $\mathrm{K}$ requirement is produced by intestinal bacteria. The carboxylation of protein depends on vitamin $\mathrm{K}$ as a cofactor in this process. After translation, this microsomal enzyme becomes responsible for the conversion of special glutamyl to gamma-carboxy glutamic residue found in a few proteins ${ }^{54}$.

\section{VITAMIN K-DEPENDENT CARBOXYLATION}

Vitamin $\mathrm{K}$ is an essential coenzyme for the gammacarboxylation that occurs in bone proteins, such as osteocalcin ${ }^{29}$. There is evidence showing that vitamin 
$\mathrm{K}$ may have a protective effect on age-related BMD loss. Vitamin K deficiency results in the synthesis of non-carboxylated osteocalcin. Evidence shows that low serum non-carboxylated osteocalcin and phylloquinone are directly correlated with low BMD and increased risk of bone fracture caused by osteoporo$\operatorname{sis}^{55}$. In a well-known cohort study by nurses, the increased risk of pelvic fracture in women was attributed to the lack of dietary phylloquinone intake ${ }^{27}$. The Framingham cohort study showed that low intake of phylloquinone was associated with increased risk of pelvic fracture in the elderly. Despite this, no correlation was observed between the intake of phylloquinone and $\mathrm{BMD}^{29}$. In a study conducted on 155 healthy postmenopausal women aged 50-60 years to determine the effect of phylloquinone, it was found that the intake of phylloquinone decreased the likelihood of femoral neck osteoporosis by $35 \%$ in the case group, as compared with the control group ${ }^{29}$.

\section{Magnesium}

Magnesium is essential for the function of many key organs and has an important role in the physiology of humans and other mammals. The presence of magnesium is vital in bone and teeth structures and has a role in more than 300 enzymes as a cofactor, including binding to ATP for kinase reactions, permeability of excitable membranes, and neuromuscular transmission. Despite these significant tasks, the physiology and homeostasis of magnesium continue to remain largely unknown. The majority of the human population does not receive adequate dietary magnesium $^{56}$. In the US, three-fourths of the population has magnesium deficiency. More than half of the body magnesium requirement (60\%) is stored in the bones, and the remaining $30-40 \%$ is stored in skeletal muscles and soft tissues, while only $1 \%$ is stored in bodily liquids ${ }^{57}$. Magnesium is an intracellular cation, and thus serum magnesium level is not a good predictor of magnesium level in the body. Because of this, many patients visiting medical centers are unaware of their low magnesium levels ${ }^{56}$. Magnesium deficiency can result in endothelial dysfunction that damages bone health. In addition, magnesium deficiency leads to greater release of inflammatory cytokines, and subsequently bone remodeling and osteopenia ${ }^{55}$. In addition, because magnesium has a mitogenic impact on osteoblasts, its deficiency inhibits cellular growth and results in the formation of larger and perfect hydroxyapatite crystals ${ }^{58}$. From this, osteoporosis is facilitated, via induction of bone fragility and weakness, limited bone formation and expansion, and the appearance of trabecular microfractures ${ }^{16}$. Reduced magnesium levels increase the release of free radicals, which may damage the skeletal muscle structure, specifically their sarcoplasm reticula and mitochondria ${ }^{59}$. Moreover, magnesium deficiency indirectly affects bone structure through the regulation of PTH levels and serum $1,25(\mathrm{OH})_{2} \mathrm{D}_{3}$ levels, which finally result in hypocalcemia. Because magnesium acts as a cofactor in the creation of PTH, a low magnesium level decreases the secretion of $\mathrm{PTH}$, which results in $1,25(\mathrm{OH})_{2} \mathrm{D}_{3}$ deficiency ${ }^{16}$. Magnesium can intervene with calciotropic hormone function, and is known as a neutralizer of calcium. It seems that the ratio of magnesium to calcium is a determining factor in bone physiology and pathology. A study showed that the ratio of serum and hair levels of calcium to magnesium is a good index for the measurement of BMD ${ }^{60}$. Various small epidemiological studies have reported that high magnesium intake is associated with high BMD in the elderly ${ }^{61}$. In addition, small clinical trials have shown that magnesium supplementation in people with low magnesium levels has had a positive impact on reduced $\mathrm{BMD}^{62}$. In a study conducted in Israel, a group of postmenopausal women received magnesium supplements (250-750 $\mathrm{mg}$ /day) for 24 months. It was observed that the BMD in trabecular bones increased by up to $8 \%$, and BMD loss was reduced in $87 \%$ of cases ${ }^{63}$. Despite this, existing evidence with respect to magnesium supplements is inadequate, and results from observational and interventional studies into the relation of magnesium and bone health are not definitive. According to a recent study, high intake of magnesium is associated with the risk of forearm fracture ${ }^{64}$.

\section{Zinc}

Zinc is an essential growth element. This element acts as a cofactor in the synthesis of AND and ANR polymerase, and enzymes involved in the production of proteins. Zinc is part of the structure of more than 200 enzymes and seems essential for the normal synthesis of collagen and bone mineralization ${ }^{65}$. Animal studies have shown that zinc deficiency is associated with abnormal bone growth and mineralization ${ }^{66}$. The strong correlation between the zinc content of bone and high BMD can demonstrate the important role of zinc in bone health ${ }^{67}$. Inadequate bone growth is very common under the condition of zinc deficiency during the growth period in animals and children ${ }^{68}$. Reduced growth is a feature of acrodermatitis enteropathica, an autosomal recessive disorder that reduces the zinc level in neonates ${ }^{69}$. Studies with rats have shown that serum zinc deficiency 
reduces zinc density in the thigh bone, consequently decreasing trabecular bone density and causing bone turnover ${ }^{70}$. Moreover, zinc has a structural role in the bone matrix. Bone minerals are composed of hydroxyapatite crystals that include a zinc-fluoride combination. Zinc also stimulates the formation of bone osteoblasts and prevents bone resorption by osteoclasts. Thus, zinc is essential for osteoblastic activities; it directly causes the activation of aminoacyl tRNA synthesis and stimulates cellular protein synthesis. This element, as a cofactor of alkaline phosphatase, stimulates bone mineralization ${ }^{71}$. Studies of rat bone marrow have shown that zinc inhibits bone resorption by preventing the formation of osteoblastlike cells ${ }^{72}$. According to these reports, the low intake of zinc is associated with low BMD in women; in addition, women with osteoporosis have had lower plasma zinc levels and greater urinary excretion of zinc ${ }^{73}$. An epidemiological study showed that the risk of fracture was significantly greater in men with lower zinc intake than in those with high zinc intake ${ }^{74}$.

\section{Copper}

Severe copper deficiency results in skeletal problems. Studies have shown that osteoporosis is related to Menkes syndrome ${ }^{75}$, which genetically disrupts the intake of copper in the body. The role of copper in bone metabolism can first be connected to the copperrelated enzyme called lysyl oxidase. This enzyme is essential for the formation of chemical bonds derived from lysine in collagen and elastin ${ }^{76}$. Animal studies have shown that the activity of this enzyme is stimulated in response to increased dietary intake of copper ${ }^{77}$. Copper plays a key role in bone resorption, which is done through the superoxide dismutase enzyme, in which copper acts as a cofactor. Superoxide dismutase is an antioxidant enzyme formed with zinc and copper atoms. The role of these two elements is the neutralization of antioxidant radicals that are produced during bone resorption by osteoclasts. Studies of animals with inadequate copper intake have shown that copper deficiency inhibits osteoclast activities but does not affect osteoblast activities ${ }^{78}$.

\section{NON-NUTRITIVE SUBSTANCES AND OSTEOPOROSIS}

\section{Phytoestrogens}

In the past, it was believed that estrogen was created only in animals. Later, it was found that plants are also capable of producing estrogen-like molecules called phytoestrogens ${ }^{79}$. Phytoestrogens are plant compounds with an estrogen-like chemical structure and a similar impact on the bone tissue. Phytoestrogens show estrogen-like activities and, due to structural similarity, have a high tendency to combine with the estrogen receptor beta ${ }^{78}$. They are among the most important isoflavones. Soy and flaxseed proteins are the most common sources of phytoestrogens ${ }^{80}$. In recent years, several studies have been conducted on soy isoflavones and their effects not only on sexual hormone metabolism but also on other biological activities, including reduced cholesterol level, risk of cancer, and protection of bone health ${ }^{81}$. In terms of mechanisms, evidence shows that isoflavones not only reduce bone resorption but also increase the formation of bone tissue at the same time. In a study of postmenopausal women, it was found that urinary excretion of deoxypyridinoline decreases with increased intake of soy protein. Deoxypyridinoline in urine is an indicator of bone resorption ${ }^{82}$. Isoflavones increase bone formation at least in two ways: first, through the activation of estrogen receptors, causing the increased activation of osteoblasts ${ }^{83}$, and second, by increasing the production of IGF-1 ${ }^{84}$. Studies have shown that IGF-1 increases osteoblastic activity in humans and has a direct relationship with $\mathrm{BMD}^{85}$. In a six-month-long study on postmenopausal women, the subjects were divided into three groups; the first and second groups received $90 \mathrm{mg}$ and $56 \mathrm{mg}$ of isoflavones, respectively, while the third group did not receive isoflavones at all. It was observed that those who received the highest amount of isoflavones had a greater BMD level (2.2\%) in the vertebral column area, as compared with the control group ${ }^{86}$. Despite this, further prospective interventional studies with longer implementation and larger sample size are required to determine the effect of phytoestrogenenriched diets on bone mass loss and reduced risk of fracture.

\section{Osteoporosis and Nutritive Status in Iran}

There are no accurate statistics on the prevalence of osteoporosis in Iran. In a study conducted in Tehran on a group of women aged 40-60 years, the prevalence of osteoporosis among postmenopausal women was reported as $23.1 \%$ and $4.6 \%$ in the vertebral column and femoral neck areas, respectively. These findings indicated a low prevalence of osteoporosis in this city ${ }^{87}$. Another study by Mojibian et al. in postmenopausal women in Yazd reported the prevalence of osteoporosis in the femoral and vertebral column regions as $43.03 \%$ and $20.5 \%$, respectively ${ }^{88}$. Another study in Mashhad showed the prevalence of osteoporosis (35.7\%) and osteopenia (38.9\%) in the lumbar 
vertebrae of women aged $50-80$ years ${ }^{89}$. This difference in the prevalence of osteoporosis and osteopenia in different societies can be due to different reasons, including differences in lifestyle, age of subjects, measuring instruments, BMD, race, and BMD measurement region ${ }^{90}$.

Quantitative studies in Iran have addressed the nutritional status of patients with osteoporosis. A study conducted in the northwest region of Iran showed a significant difference between dietary intake of nutrients and the recommended dietary allowance ${ }^{91}$. For example, adequate intake of calcium, vitamin $\mathrm{D}$, and vitamin $\mathrm{K}$ was observed only in $7.2 \%, 3.1 \%$, and $42.3 \%$ of cases, respectively ${ }^{92}$. Nevertheless, further studies in different parts of the country are required.

\section{CONCLUSION}

In general, having good nutrition plays a very significant role in osteoporosis prevention and treatment. In other words, people can greatly improve their bone health by observing the following simple recommendations: in addition to the recommended intake of calcium $(1,200 \mathrm{mg} /$ day $)$ by the elderly over 70 years old, it is recommended they take at least 600 IU (ideally 800-1,000 IU) of vitamin D. Paying attention to adequate intake of calcium and vitamin $\mathrm{D}$ should not result in the neglect of other nutrients and dietary compounds. Other important micronutrients for bone health, such as magnesium, vitamin $\mathrm{K}$, and potassium, can be supplied by having a healthy diet containing large portions of fruits and vegetables (at least five servings per day). In addition to diet, living a good lifestyle by avoiding high-risk behaviors (e.g., excessive use of tobacco and alcohol) and by including adequate physical activity can assure bone health.

\section{ABBREVIATIONS}

BMD: Bone mass density

SFA: Saturated fatty acids

\section{ACKNOWLEDGMENTS}

Thanks to everyone who helped us with this research. We would also like to thank the Vice Chancellor for Research of Fasa University of Medical Sciences.

\section{AUTHOR'S CONTRIBUTIONS}

Hejazi J, Davoodi A, Khosravi M, Sedaghat M, Abedi V, Hosseinverdi S, Ehrampoush E, Homayounfar R and Shojaie L participated in the search and writing of the primary version of the manuscript. Homayounfar $\mathrm{R}$ was involved in editing, submitting, and finalizing the manuscript.

\section{FUNDING}

Not applicable.

\section{AVAILABILITY OF DATA AND MATERIALS}

Not applicable.

\section{ETHICS APPROVAL AND CONSENT TO PARTICIPATE}

Not applicable.

\section{CONSENT FOR PUBLICATION}

Not applicable.

\section{COMPETING INTERESTS}

The authors declare that they have no competing interests.

\section{REFERENCES}

1. Lowe NM, Fraser WD, Jackson MJ. Is there a potential therapeutic value of copper and zinc for osteoporosis? Proceedings of the Nutrition Society. 2002;61(02):181-185. PMID: 12133199. Available from: https://doi.org/10.1079/ PNS2002154.

2. Askari A, Ehrampoush E, Homayounfar $R$, Arasteh $P$ Naghizadeh MM, Yarahmadi M, et al. Relationship between metabolic syndrome and osteoarthritis: The Fasa Osteoarthritis Study. Diabetes \& Metabolic Syndrome: Clinical Research \& Reviews. 2017;PMID: 28690163. Available from: https://doi.org/10.1016/j.dsx.2017.07.002.

3. Johnell $O$. The socioeconomic burden of fractures: today and in the 21st century. The American journal of medicine 1997; ;103(2):S20-S6. Available from: https://doi.org/10.1016/S00029343(97)90023-1.

4. Riaudel T, Guillot P, Decker LD, Gouraud-Tanguy A, Pichierri $\mathrm{S}$, Chevalet $\mathrm{P}$, et al. Nutrition and osteoporosis in elderly. Geriatrie et psychologie neuropsychiatrie du vieillissement. 2011;9(4):399-408. PMID: 22182816. Available from: https: //doi.org/10.1684/pnv.2011.0310.

5. Melton LJ, Chrischilles EA, Cooper C, Lane AW, Riggs BL. How many women have osteoporosis? Journal of bone and mineral research. 2005;20(5):886-892. PMID: 15931736. Available from: https://doi.org/10.1359/jbmr.2005.20.5.886.

6. Shahbazi R, Akbari ME, Hashemian M, Abbasi M, Jalali S, Homayounfar $R$, et al. High body mass index and young age are not associated with post-mastectomy pain syndrome in breast cancer survivors: A case-control study. Iranian journal of cancer prevention. 2015;8(1):29.

7. Munshi R, Kochhar A. Nutritional Implications of Osteoporosis among Post Menopausal Women in India. International Journal of Health Sciences and Research (IJHSR). 2014;4(4):157165.

8. GR C, SI B. Protein and bone health: literature review and counselling implications. Canadian Journal of Dietetic Practice and Research. 2003;64(1):5-11. PMID: 12631403. Available from: https://doi.org/10.3148/64.1.2003.5.

9. Nieves J. Skeletal effects of nutrients and nutraceuticals, beyond calcium and vitamin D. Osteoporosis International. 2013;24(3):771-786. PMID: 23152094. Available from: https: //doi.org/10.1007/s00198-012-2214-4. 
10. Lambert H, Huggett C, Gannon R, Lanham-New SA. AcidBase Homeostasis and Skeletal Health: Current Thinking and Future Perspectives. Nutritional Influences on Bone Health: Springer. 2013;p. 93-98. PMID: 24126088. Available from: https://doi.org/10.1007/978-1-4471-2769-7_8.

11. Welch AA, Mulligan A, Bingham SA, Khaw KT. Urine $p H$ is an indicator of dietary acid-base load, fruit and vegetables and meat intakes: results from the European Prospective Investigation into Cancer and Nutrition (EPIC)-Norfolk population study. British Journal of Nutrition. 2008;99(06):13351343. PMID: 18042305. Available from: https://doi.org/10. 1017/S0007114507862350.

12. Darling AL, Millward DJ, Torgerson DJ, Hewitt CE, LanhamNew SA. Dietary protein and bone health: a systematic review and meta-analysis. The American journal of clinical nutrition. 2009;ajcn:27799. PMID: 19889822. Available from: https://doi.org/10.3945/ajen.2009.27799.

13. Munger RG, Cerhan JR, Chiu BC. Prospective study of dietary protein intake and risk of hip fracture in postmenopausal women. The American journal of clinical nutrition. 1999;69(1):147-152. PMID: 9925137. Available from: https://doi.org/10.1093/ajcn/69.1.147.

14. Orwoll $\mathrm{E}$. The effects of dietary protein insufficiency and excess on skeletal health. Bone. 1992;13(4):343-350. Available from: https://doi.org/10.1016/8756-3282(92)90081-7.

15. Dargent-Molina P, Sabia S, Touvier M, Kesse E, Bréart G, ClavelChapelon F, et al. Proteins, dietary acid load, and calcium and risk of postmenopausal fractures in the E3N French women prospective study. Journal of Bone and Mineral Research. 2008;23(12):1915-1922. PMID: 18665794. Available from: https://doi.org/10.1359/jbmr.080712.

16. Kerstetter JE, Kenny AM, Insogna KL. Dietary protein and skeletal health: a review of recent human research. Current opinion in lipidology. 2011;22(1):16-20. PMID: 21102327. Available from: https://doi.org/10.1097/MOL. 0b013e3283419441.

17. Zand $H$, Homayounfar $R$, Cheraghpour M, Jeddi-Tehrani $M$ Ghorbani A, Pourvali K, et al. Obesity-induced p53 activation in insulin-dependent and independent tissues is inhibited by beta-adrenergic agonist in diet-induced obese rats. Life sciences. 2016;147:103-109. PMID: 26827989. Available from: https://doi.org/10.1016/j.lfs.2016.01.040.

18. Cao JJ, Johnson LK, Hunt JR. A diet high in meat protein and potential renal acid load increases fractional calcium absorption and urinary calcium excretion without affecting markers of bone resorption or formation in postmenopausal women. The Journal of nutrition. 2011;141(3):391-397. PMID: 21248199. Available from: https://doi.org/10.3945/jn.110. 129361.

19. Hunt JR, Johnson LK, Roughead ZF. Dietary protein and calcium interact to influence calcium retention: a controlled feeding study. The American journal of clinical nutrition 2009;;89(5):1357-1365. PMID: 19279077. Available from: https://doi.org/10.3945/ajcn.2008.27238.

20. Kerstetter JE, O'Brien KO, Caseria DM, Wall DE, Insogna KL. The impact of dietary protein on calcium absorption and kinetic measures of bone turnover in women. The journal of clinical endocrinology \& metabolism. 2005;90(1):26-31. PMID: 15546911. Available from: https://doi.org/10.1210/jc.20040179.

21. Garnero P, Sornay-Rendu E, Delmas PD. Low serum IGF-1 and occurrence of osteoporotic fractures in postmenopausal women. The Lance. 2000;355(9207):898-899. Available from: https://doi.org/10.1016/S0140-6736(99)05463-X.

22. Zhang J, Zhang G, Yang R, Niu S, Bai W, Liu D, et al. Cloning and Characterization of Four New Splice Variants of InsulinLike Growth Factor-I Gene in Chinese Red Steppes. Journal of Animal and Veterinary Advances. 2011;10(18):2459-2464.

23. Thorpe DL, Knutsen SF, Beeson WL, Rajaram S, Fraser GE. Effects of meat consumption and vegetarian diet on risk of wrist fracture over 25 years in a cohort of peri-and postmenopausal women. Public health nutrition. 2008;11(06):564-572.
PMID: 17686206. Available from: https://doi.org/10.1017/ S1368980007000808

24. Michaëlsson $K$, Holmberg $L$, Mallmin $H$, Wolk A, Bergström $\mathrm{R}$, Ljunghall S. Diet, bone mass, and osteocalcin: a crosssectional study. Calcified tissue international. 1995;57(2):8693. Available from: https://doi.org/10.1007/BF00298425PMid: 7584880 .

25. Lacey JM, Anderson JJ, Fujita T, Yoshimoto Y, Fukase M, Tsuchie $S$, et al. Correlates of cortical bone mass among premenopausal and postmenopausal Japanese women. Journal of Bone and Mineral Research. 1991;6(7):651-659. PMID: 1950670. Available from: https://doi.org/10.1002/jbmr. 5650060702.

26. Rapuri PB, Gallagher JC, Haynatzka V. Protein intake: effects on bone mineral density and the rate of bone loss in elderly women. The American journal of clinical nutrition. 2003;77(6):1517-1525. PMID: 12791633. Available from: https://doi.org/10.1093/ajcn/77.6.1517.

27. Corwin RL, Hartman TJ, Maczuga SA, Graubard BI. Dietary saturated fat intake is inversely associated with bone density in humans: analysis of NHANES III. The Journal of nutrition. 2006;136(1):159-165. PMID: 16365076. Available from: https://doi.org/10.1093/jn/136.1.159.

28. Askari A, Naghizadeh MM, Homayounfar R, Shahi A, Afsarian $\mathrm{MH}$, Paknahad, et al. Increased serum levels of IL-17A and IL23 are associated with decreased vitamin D3 and increased pain in osteoarthritis. PloS one. 2016;11(11):e0164757. PMID: 27820818. Available from: https://doi.org/10.1371/journal. pone. 0164757 .

29. Weiss LA, Barrett-Connor E, von Mühlen D. Ratio of $n-6$ to $\mathrm{n}-3$ fatty acids and bone mineral density in older adults: the Rancho Bernardo Study. The American journal of clinical nutrition. 2005;81(4):934-938. PMID: 15817874. Available from: https://doi.org/10.1093/ajcn/81.4.934.

30. Watkins BA, Li Y, Lippman HE, Seifert MF. Omega-3 polyunsaturated fatty acids and skeletal health. Experimental Biology and Medicine. 2001;226(6):485-497. PMID: 11395919. Available from: https://doi.org/10.1177/153537020122600601.

31. Ehrampoush $E$, Arasteh $P$, Homayounfar R, Cheraghpour $M$ Alipour M, Naghizadeh MM, et al. New anthropometric indices or old ones: Which is the better predictor of body fat? Diabetes \& Metabolic Syndrome: Clinical Research \& Reviews. 2017;11(4):257-263. Available from: https://doi.org/10.1016/j. dsx.2016.08.027PMid:27578617.

32. Go JH, Song YM, Park JH, Park JY, Choi YH. Association between serum cholesterol level and bone mineral density at lumbar spine and femur neck in postmenopausal Korean women. Korean journal of family medicine. 2012;33(3):166173. PMID: 22787539. Available from: https://doi.org/10.4082/ kjfm.2012.33.3.166.

33. Stránský M, Rysava L. Nutrition as prevention and treatment of osteoporosis. Physiological research. 2009;58:S7.

34. Heaney RP. Calcium, dairy products and osteoporosis. Journal of the American College of Nutrition. 2000;19(sup2):83S99S. PMID: 10759135. Available from: https://doi.org/10.1080/ 07315724.2000.10718088.

35. Sanders KM, Nowson CA, Kotowicz MA, Briffa K, Devine A, Reid IR. Calcium and bone health: position statement for the Australian and New Zealand Bone and Mineral Society, Osteoporosis Australia and the Endocrine Society of Australia. Med J Aust. 2009;190(6):316-320. PMID: 19296813. Available from: https://doi.org/10.5694/j.1326-5377.2009.tb02421.x.

36. Garriguet D. Bone health: osteoporosis, calcium and vitamin D. Health reports. 2011;22(3):7.

37. Rodrıguez-Martınez M, Garcıa-Cohen E. Role of Ca $2+$ and vita$\min \mathrm{D}$ in the prevention and treatment of osteoporosis. Pharmacology \& therapeutics. 2002;93(1):37-49. Available from: https://doi.org/10.1016/S0163-7258(02)00164-X.

38. Holick MF, Chen TC. Vitamin D deficiency: a worldwide problem with health consequences. The American journal of clinical nutrition. 2008;87(4):1080S-1086S. PMID: 18400738. 
Available from: https://doi.org/10.1093/ajcn/87.4.1080S.

39. Mosekilde L. Vitamin $D$ and the elderly. Clinical endocrinology. 2005;62(3):265-281. PMID: 15730407. Available from: https://doi.org/10.1111/j.1365-2265.2005.02226.x.

40. Holick MF, Binkley NC, Bischoff-Ferrari HA, Gordon CM, Hanley DA, Heaney RP, et al. Evaluation, treatment, and prevention of vitamin $D$ deficiency: an Endocrine Society clinical practice guideline. The Journal of Clinical Endocrinology \& Metabolism. 2011;96(7):1911-1930. PMID: 21646368. Available from: https://doi.org/10.1210/jc.2011-0385.

41. Prentice A. Vitamin D deficiency: a global perspective. Nutrition reviews. 2008;66(suppl 2):S153-S64. PMID 18844843. Available from: https://doi.org/10.1111/j.17534887.2008.00100.x

42. Malabanan AO, Holick MF. Vitamin D and bone health in postmenopausal women. Journal of Women's Health. 2003;12(2):151-156. PMID: 12737713. Available from: https: //doi.org/10.1089/154099903321576547.

43. Andersson U, Litton MJ, Fehniger TE, Ulfgren AK, Andersson J. Detection and quantification of cytokine-producing cells by immunostaining. Techniques in Quantification and Localization of Gene Expression: Springer. 2000;p. 55-79. Available from: https://doi.org/10.1007/978-1-4612-1342-0 5.

44. Kavitha P, Ramana J, Prasad JR. Role of Vitamins in Immune Response. Intas Polivet. 2007;8(1):11-19.

45. Amouzougan A, Chopin F, Laporte S, Vico L, Thomas T. Functional hypoparathyroidism in postmenopausal women with fragility fracture. Joint Bone Spine. 2012;79(2):170-175. PMID: 21664167. Available from: https://doi.org/10.1016/j.jbspin. 2011.04.005.

46. Atli T, Gullu S, Uysal A, Erdogan G. The prevalence of vitamin $D$ deficiency and effects of ultraviolet light on vitamin $D$ levels in elderly Turkish population. Archives of gerontology and geriatrics. 2005;40(1):53-60. PMID: 15531023. Available from: https://doi.org/10.1016/j.archger.2004.05.006.

47. Holick MF. Vitamin D deficiency. New England Journal of Medicine. 2007;357(3):266-281. PMID: 17634462. Available from: https://doi.org/10.1056/NEJMra070553.

48. Kemi VE, Kärkkäinen MU, Rita HJ, Laaksonen MM, Outila TA Lamberg-Allardt CJ. Low calcium: phosphorus ratio in habitual diets affects serum parathyroid hormone concentration and calcium metabolism in healthy women with adequate calcium intake. British journal of nutrition. 2010;103(04):561568. PMID: 19781123. Available from: https://doi.org/10.1017/ S0007114509992121.

49. Heaney RP. Phosphorus nutrition and the treatment of osteoporosis. Mayo Clinic Proceedings. 2004: Elsevier;PMID: 14708952. Available from: https://doi.org/10.4065/79.1.91

50. Heaney RP, Nordin B. Calcium effects on phosphorus absorption: implications for the prevention and co-therapy of osteoporosis. Journal of the American College of Nutrition. 2002;21(3):239-244. PMID: 12074251. Available from: https: //doi.org/10.1080/07315724.2002.10719216.

51. Son SM, Chun YN. Effect of oral therapy with alphacalcidol or calcium in Korean elderly women with osteopenia and low dietary calcium. Nutrition Research. 2001;21(10):1347-1355. Available from: https://doi.org/10.1016/S0271-5317(01)003177.

52. Shakoor S, llyas F, Abbas N, Mirza MA, Arif S. Prevalence of osteoporosis in relation to serum calcium and phosphorus in aging women. J Glob Innov Agric Soc Sci. 2014;2(2):70-75. Available from: https://doi.org/10.17957/JGIASS/2.2.511.

53. Slinin Y, Blackwell T, Ishani A, Cummings SR, Ensrud KE. Investigators M. Serum calcium, phosphorus and cardiovascular events in post-menopausal women. International journal of cardiology. 2011;149(3):335-340. Available from: https: //doi.org/10.1016/j.ijcard.2010.02.013PMid:20189664.

54. Booth SL, Dallal G, Shea MK, Gundberg C, Peterson JW, Dawson-Hughes $\mathrm{B}$. Effect of vitamin $\mathrm{K}$ supplementation on bone loss in elderly men and women. The Journal of Clinical Endocrinology \& Metabolism. 2008:93(4):1217-1223. PMID: 18252784. Available from: https://doi.org/10.1210/jc.2007-
2490

55. Castiglioni S, Cazzaniga A, Albisetti W, Maier JA. Magnesium and osteoporosis: current state of knowledge and future research directions. Nutrients. 2013;5(8):3022-3033. PMID: 23912329. Available from: https://doi.org/10.3390/nu5083022.

56. Long S, Romani AM. Role of Cellular Magnesium in Human Diseases. Austin journal of nutrition and food sciences. 2014;2(10).

57. Romani AM. Magnesium in health and disease. Interrelations between Essential Metal lons and Human Diseases: Springer. 2013;p. 49-79. PMID: 24470089. Available from: https://doi org/10.1007/978-94-007-7500-8_3.

58. Rude R, Gruber H, Wei L, Frausto A, Mills B. Magnesium deficiency: effect on bone and mineral metabolism in the mouse. Calcified tissue internationa. 2003;72(1):32-41. PMID 12370796. Available from: https://doi.org/10.1007/s00223001-1091-1.

59. Santos DA, Matias CN, Monteiro CP, Silva AM, Rocha PM, Minderico $C S$, et al. Magnesium intake is associated with strength performance in elite basketball, handball and volleyball players. Magnesium Research. 2012;24(4):215-219. PMID: 21983266. Available from: https://doi.org/10.1684/mrh.2011. 0290.

60. Song CH, Barrett-Connor E, Chung JH, Kim SH, Kim KS. Associations of calcium and magnesium in serum and hair with bone mineral density in premenopausal women. Biological trace element research. 2007;118(1):1-9. PMID: 17848724. Available from: https://doi.org/10.1007/s12011-007-0011-2.

61. Yoon EH, Noh H, Lee HM, Hwang HS, Park HK, Park YS. Bone mineral density and food-frequency in Korean adults: The 2008 and 2009 Korea National Health and Nutrition Examination Survey. Korean journal of family medicine. 2012;33(5):287-295. PMID: 23115703. Available from: https: //doi.org/10.4082/kjfm.2012.33.5.287.

62. Rejnmark L, Vestergaard P, Hermann A, Brot C, Eiken P, Mosekilde L. Dietary intake of folate, but not vitamin B2 or B12, is associated with increased bone mineral density 5 years after the menopause: results from a 10-year follow-up study in early postmenopausal women. Calcified tissue international. 2008;82(1):1-11. PMID: 18175033. Available from: https://doi.org/10.1007/s00223-007-9087-0.

63. L O, I O, O M, A S. Effect of dietary magnesium on glucose tolerance and plasma lipid during oral contraceptive administration in female rats. African journal of medicine and medical sciences. 2008;37(2):135-139.

64. Jackson R, Bassford T, Cauley J, Chen Z, LaCroix A, Sparks $A$, et al. The impact of magnesium intake on fractures: Results from the women's health initiative observational study (WHI-OS). JOURNAL OF BONE AND MINERAL RESEARCH; WILEY-BLACKWELL COMMERCE PLACE, 350 MAIN ST, MALDEN 02148, MA USA. 2002;.

65. Arikan DC, Coskun A, Ozer A, Kilinc M, Atalay F, Arikan T. Plasma selenium, zinc, copper and lipid levels in postmenopausal Turkish women and their relation with osteoporosis. Biological trace element research. 2011;144(1-3):407417. PMID: 21656042. Available from: https://doi.org/10.1007/ s12011-011-9109-7.

66. Kwun IS, Cho YE, Lomeda RAR, Shin HI, Choi JY, Kang YH, et al. Zinc deficiency suppresses matrix mineralization and retards osteogenesis transiently with catch-up possibly through Runx 2 modulation. Bone. 2010;46(3):732-741. PMID: 19913120 Available from: https://doi.org/10.1016/j.bone.2009.11.003.

67. Hill T, Meunier N, Andriollo-Sanchez M, Ciarapica D, HiningerFavier I, Polito A, et al. The relationship between the zinc nutritive status and biochemical markers of bone turnover in older European adults: the ZENITH study. European journal of clinical nutrition. 2005;59:S73-S8. PMID: 16254587. Available from: https://doi.org/10.1038/sj.ejcn.1602303.

68. Norii T. Relationship between zinc parameters and either body weight gain, protein intake or survival time in zincdeficient rats. Journal of nutritional science and vitaminol- 
ogy. 2005;51(6):433-439. PMID: 16521703. Available from: https://doi.org/10.3177/jnsv.51.433.

69. Prasad AS. Biochemistry of zinc. Springer Science \& Business Media. 2013;

70. Erben RG, Lausmann K, Roschger P, Schüler C, Skalicky M Klaushofer $\mathrm{K}$, et al. Long-term marginal zinc supply is not detrimental to the skeleton of aged female rats. The Journal of nutrition. 2009;139(4):703-709. PMID: 19211826. Available from: https://doi.org/10.3945/jn.108.099077.

71. Uysal T, Ustdal A, Sonmez MF, Ozturk F. Stimulation of bone formation by dietary boron in an orthopedically expanded suture in rabbits. The Angle orthodontist. 2009;79(5):984990. PMID: 19705952. Available from: https://doi.org/10.2319/ 112708-604.1.

72. Yamaguchi $M$, Igarashi A, Sakai M, Degawa H, Ozawa Y. Prolonged intake of dietary fermented isoflavone-rich soybean reinforced with zinc affects circulating bone biochemical markers in aged individuals. Journal of health science. 2005;51(2):191-196. Available from: https://doi.org/10.1248/ jhs.51.191.

73. Hyun TH, Barrett-Connor E, Milne DB. Zinc intakes and plasma concentrations in men with osteoporosis: the Rancho Bernardo Study. The American journal of clinical nutrition. 2004;80(3):715-721. PMID: 15321813. Available from: https://doi.org/10.1093/ajcn/80.3.715.

74. Hosea HJ, Taylor CG, Wood T, Mollard R, Weiler HA. Zincdeficient rats have more limited bone recovery during repletion than diet-restricted rats. Experimental Biology and Medicine. 2004;229(4):303-311. PMID: 15044713. Available from: https://doi.org/10.1177/153537020422900404.

75. Johnson WT. 17 Copper and Brain Function. Nutritional Neuroscience. 2005;p. 289

76. Borkow G, Gabbay J, Dardik R, Eidelman Al, Lavie Y, Grunfeld $Y$, et al. Molecular mechanisms of enhanced wound healing by copper oxide-impregnated dressings. Wound repair and regeneration. 2010;18(2):266-275. PMID: 20409151. Available from: https://doi.org/10.1111/j.1524-475X.2010.00573.x.

77. Odabasi E, Turan M, Aydin A, Akay C, Kutlu M. Magnesium, zinc, copper, manganese, and selenium levels in postmenopausal women with osteoporosis. Can magnesium play a key role in osteoporosis? Annals of the Academy of Medicine, Singapore. 2008;37(7):564-567.

78. Sirtori CR. Risks and benefits of soy phytoestrogens in cardiovascular diseases, cancer, climacteric symptoms and osteoporosis. Drug safety. 2001;24(9):665-682. PMID: 11522120. Available from: https://doi.org/10.2165/00002018-20012409000003.

79. Gordon P, Khojasteh SC. A decades-long investigation of acute metabolism-based hepatotoxicity by herbal constituents: a case study of pennyroyal oil. Drug metabolism reviews. 2015;47(1):12-20. PMID: 25512112. Available from: https://doi.org/10.3109/03602532.2014.990032.

80. Nordee SK, Bona BJ, Jones DN, Lambert JR, Jackson TA. Endocrine disrupting activities of the flavonoid nutraceuticals luteolin and quercetin. Hormones and Cancer. 2013;4(5):293-
300. PMID: 23836117. Available from: https://doi.org/10.1007/ s12672-013-0150-1.

81. Arjmandi BH, Smith BJ. Soy isoflavones' osteoprotective role in postmenopausal women: mechanism of action. The Journal of nutritional biochemistry. 2002;13(3):130-137. Available from: https://doi.org/10.1016/S0955-2863(02)00172-9.

82. Ma DF, Qin LQ, Wang PY, Katoh R. Soy isoflavone intake increases bone mineral density in the spine of menopausa women: meta-analysis of randomized controlled trials. Clinical nutrition. 2008;27(1):57-64. PMID: 18063230. Available from: https://doi.org/10.1016/j.clnu.2007.10.012.

83. Jo HJ, Choi MJ. Effects of isoflavone supplementation on the bone mineral density of growing female rats. Nutrition research and practice. 2008;2(2):68-73. PMID: 20126368. Available from: https://doi.org/10.4162/nrp.2008.2.2.68.

84. Devareddy L, Khalil DA, Smith BJ, Lucas EA, Soung DY, Marlow $\mathrm{DD}$, et al. Soy moderately improves microstructural properties without affecting bone mass in an ovariectomized rat model of osteoporosis. Bone. 2006;38(5):686-693. PMID: 16406762. Available from: https://doi.org/10.1016/j.bone.2005.10.024.

85. Seck T, Scheidt-Nave C, Leidig-Bruckner G, Ziegler $R$, Pfeilschifter J. Low serum concentrations of insulin-like growth factor I are associated with femoral bone loss in a population-based sample of postmenopausal women. Clinical endocrinology. 2001;55(1):101-106. PMID: 11453958. Available from: https://doi.org/10.1046/j.1365-2265.2001. 01278.x.

86. Kim HYP, Han YH, Kim MH, Kim KS. Effects of Different Kinds of Korean Soybeans on Body Lipids and Lipid Peroxidation in Rats. Korean Journal of Nutrition. 2007;40(3):229-234. Available from: https://doi.org/10.4163/kjn.2012.45.3.229.

87. Tehrani MJ, Kalantari N, Azadbakht L, Rajaie A, Hooshiar-rad A, Golestan B, et al. The Prevalence of osteoporosis among women aged 40-60 in Tehran. Iranian Journal of Endocrinology and Metabolism. 2003;5(4):271-276.

88. Mojibian M, Oulia M, BEIKI BO, KOUCHAK YL. Osteoporosis in postmenopausal women. 2006;.

89. Rajabian RLP, Parizade M, Larijani M. The prevalence of osteoporosis in Mashhad. Medical Journal of Mashhad. 2006;49:145-152.

90. Babai MA, Arasteh P, Hadibarhaghtalab M, Naghizadeh MM, Salehi A, Askari A, et al. Defining a BMI Cut-Off Point for the Iranian Population: The Shiraz Heart Study. PLoS ONE. 2016;11(8):e0160639-e. PMID: 27509026. Available from: https://doi.org/10.1371/journal.pone.0160639.

91. Germano A, Priola S, Angileri FF, Conti A, Torre DL, Cardali S et al. Long-term follow-up of ruptured intracranial aneurysms treated by microsurgical wrapping with autologous muscle. Neurosurg Rev discussion 32. 2013;36(1):123-131. PMID 22777660. Available from: https://doi.org/10.1007/s10143012-0408-z.

92. Hejazi J, Mohtadinia J, Kolahi S, Ebrahimi-Mamaghani M. Nutritional status among postmenopausal osteoporotic women in North West of Iran. Asia Pacific journal of clinical nutrition. 2009;18(1):48-53. 